\title{
Massage or music meant to be relaxing, result in lowering salivary cortisol concentration in race horses
}

\author{
Witold Kędzierski ${ }^{1}$, Iwona Janczarek², Anna Stachurska ${ }^{2}$ and Izabela Wilk \\ ${ }^{1}$ Department of Biochemistry, University of Life Sciences in Lublin, Lublin, Poland \\ 2 Department of Horse Breeding and Use, University of Life Sciences in Lublin, Lublin, Poland
}

\begin{abstract}
Summary: At the beginning of training routine, young race horses are exposed to stressful stimuli. The aim of the study was to evaluate the influence of a relaxing massage which the horses received in the stable, and the influence of music piped into the stable, on the longlasting stress level of the horses. 120 Purebred Arabian horses were studied. They were examined during first racing season, which lasted for six months. At the beginning of the study, the horses were 28-31 months old. The horses were brought to Słužewiec Horse Race Track (Warsaw, Poland) from their familiar studs and were randomly assigned to music $(n=48)$, massage $(n=48)$, or control ( $n=24)$ groups. All horses were regularly trained and competed in official races. Once a month, saliva samples were collected from each horse to determine the cortisol concentration. Both music and massage resulted in significantly lower salivary cortisol concentration compared to control treatment.
\end{abstract}

Keywords: animal welfare, cortisol, race horses, massage, music, stress

Citation: Kędzierski W., Janczarek I., Stachurska A., Wilk I. (2017) Massage or music meant to be relaxing, result in lowering salivary cortisol concentration in race horses. Pferdeheilkunde 33, 146-151; DOI 10.21836/PEM20170206

Correspondence: Witold Kędzierski PhD, Department of Biochemistry, University of Life Sciences in Lublin, Akademicka 12, 20-033 Lublin, Poland; e-mail: witold.kedzierski@up.lublin.pl

\section{Introduction}

Young Purebred Arabian horses in Poland are routinely submitted to race training. At the age of 2.5 years, they are moved from familiar studs to an unfamiliar race training centre. Much of the stimuli accumulated at the beginning of training routine is associated with transport, change of residence, physical effort and participation in races, and can elicit chronic stress in horses (Alexander and Irvine 1998). Moreover, the commercialisation of race tracks alter the living conditions towards circumstances inconsistent with the biology of horses (MacTaggart et al. 2010). Keeping a racehorse in a box for most of the day, results in restricted freedom of movement (Henderson 2007). An unfamiliar environment, isolation, and short feed intake can also deepen the stress level (Waters et al. 2002). It is known that long-lasting stress has a negative influence on the organism. The factors generating stress in trained horses, however, can only be partially eliminated. Therefore, negative factors should be controlled and their effects should be mitigated (Evans 2003). Various relaxing methods may be used, e.g. free movement in the paddocks, massage and music. Massage promotes general body relaxation and increases the sense of an animal well-being (Scott and Swenson 2009). In horses, the heart rate measured during and immediately after a massage was reduced, and improved behavioural responses were noted (McBride et al. 2004). Horses are generally sensitive to music. The most visible sign of the influence of music on horses is the horse's ability to synchronise their movement to musical rhythm (Bregman et al. 2012). According to Carter and Greening (2012), the effect of the music on a horse's behaviour depends on the music genre. Stachurska et al. (2015) showed that relaxation music positively affected the emotional state in race horses. However, little is known how these kinds of relaxation methods reduce long-lasting stress in race horses (Scott and Swenson 2009).

The most common approach used to evaluate the stress level in horses, is measuring cortisol release (Peeters et al. 2010, Schmidt et al. 2010a, b). The cortisol is a natural glucocorticoid hormone synthetised by the adrenal cortex, which in turn, is stimulated by sympathetic nervous system activity. The main function of the hormone is to increase blood glucose level during effort and stressful conditions. In horses, the blood plasma cortisol concentration reflects not only the response to exertion (Desmecht et al. 1996, Nagata et al. 1999) but also the mental stress level (Cayado et al. 2006, Fazio et al. 2008). In recent years, in cortisol determination, more attention has been devoted to saliva sampling. This form of sampling is less stressful for the horse than blood sampling (Peeters et al. 2010, 2011). The level of the saliva cortisol correlates well with its level in the blood (van der Kolk 2001, Peeters et al. 201 1, Bohak et al. 2013). The salivary cortisol concentration was successfully used as an indicator of the stress level in horses in response to stabling (Harewood 2005), road transport (Schmidt et al. 2010a, b) and exercise (Kędzierski et al. 2013, 2014a). A significant increase in the salivary cortisol concentration was stated in naïve horses during the initial training. The increase was particularly significant in response to mounting by a rider (Schmidt et al. 2010a, Kędzierski et al. 2014b). Thus, measuring the cortisol concentration in saliva samples was assumed to be a useful marker of the mental stress in horses.

The aim of the study was to evaluate the influence of a relaxation massage, and music piped into the stable, on the horse's long-lasting stress level gauged with the salivary cortisol concentration. 


\section{Materials and methods}

This article presents data collected within a larger research project designed to determine the influence of chosen relaxation techniques on the emotional state of young race horses. The study tested the hypothesis that relaxation techniques such as massage and music used over a long period of time, decrease the salivary cortisol concentration in race horses.

\section{Horses}

In the study, 120 Purebred Arabian horses were examined over two years: 57 horses in the first year and 63 in the second year. All the horses participated in the study during their first racing season. Each horse was studied for six months, which covered the full race season for three-year old Purebred Arabian horses. At the beginning of the study, the horses were 28-31 months old. The horses were brought to Słužewiec Horse Race Track (Warsaw, Poland) from their familiar studs about three months earlier to acclimatise to the new conditions. After a month of acclimatisation, the horses began the initial training. On the first few days, they were bridled and saddled inside their boxes. Next, they were walked and trotted in an automated horse walker for $30 \mathrm{~min}$ a day. After that, the horses were mounted. The caretaker held the reins and another caretaker assisted the rider to first lay over the back of the horse and then to move to a sitting position in the saddle. This initial training lasted nine to twelve days, depending on the horse behaviour. Finally, the riders walked and trotted the horses in a paddock for 30 min a day for about six weeks.

The horses were randomly divided into three groups: control group ( $n=24)$, music group which listened to music meant to be relaxing $(n=48)$, and massage group $(n=48)$ which regularly received a relaxing massage for about $30 \mathrm{~min}$, three days a week. The only criterion of dividing the horses into the groups was that the groups were to include a similar number of mares and stallions. During the whole testing period, the horses were housed in four stables under comparable social and environmental conditions. Each horse was kept in a box stall measuring $3.5 \mathrm{~m} \times 4 \mathrm{~m}$. Straw bedding allowed the horse to comfortably lie down. To reduce the influence of nonspecific factors on the animal's emotional reaction, all the horses were fed the same diet according to dietary guidelines and cared for by the same caretakers in a manner which was typical for race horses. This means that all horses had equal exposure to all the caretakers. To minimise the influence of the year and stable factors, the experiment was arranged in a manner shown in Table 1. For the first year of the study, the massage was introduced in stables 1 and 2, and the music in stables 3 and 4 . The schedule was revised in the second year of the study. The control group was also continued in respective stables in the consecutive years.
Before the study, all of the horses were clinically sound according to a veterinarian. All the horses showed normal behaviour according to the trainer. Not all of the horses remained in training for the whole racing season because, in some cases, the owners decided to end their horse's career before the end of the season. Thus, the number in the data for each month was lower than the number of horses included in a group, and amounted to $62.5 \%-89.6 \%$.

\section{Training and Racing}

The experiment was performed according to the regular racetraining schedule, and for two race seasons. The training sessions were performed for about one hour a day, six days a week. The riders saddled the horses then walked the horses for approximately $10 \mathrm{~min}$ as a warm-up exercise. The primary race training was conducted on the sand track. The speed and duration were individually adapted to the level of each horse's performance. An exception was made for the measurement days. On the measurement days, each horse had to cover a distance of $1800 \mathrm{~m}$ at a speed of $6.4 \mathrm{~m} / \mathrm{s}$. After the exercise, the horses were put on an automatic horse walker for $45 \mathrm{~min}$. At the end of the third month of the study, the horses started to compete in official races at least once a month. A day before and two days after the race, the horses were only given 60 minutes of exercise in the automatic walker. On those days, they were not examined. All persons included in the training and maintaining of studied horses didn't know the purpose of the study.

At the end of both race seasons, the horses' performance was estimated with four parameters based on official race records: (1) number of races, in which a horse won; (2) prize per race, i.e. sum of prizes won to the number of races a horse took part; (3) success coefficient, i.e. sum of prizes won by a horse to sum of prizes won by all horses at the same age in respective race season; (4) general handicap, i.e. theoretical weight (in $\mathrm{kg}$ ) a horse should carry in a race to equal the horse's chance to win the race, with the chances of other horses at the same age.

\section{Listening to Music}

For approximately five hours a day, music group listened to music piped into their stalls. The music was played in the stable from 1 to 6 o'clock p.m. The music used was specifically composed and recorded by J. Marlow, the specialist in the music for animals. The rhythm and sound frequency of the composition were intended to be within the sensitivity of the equine hearing range (Saslow 2002, Wells 2009). The relaxation music CD contains 10 movie-like soundtracks of New Age genre, played with J. Marlow's ten-string guitar. The music was heard in the stable through a loudspeaker (My Pet

\begin{tabular}{lcccc}
\hline Table 1 & Organization of the groups of horses & & & \\
\hline Year of the study & Stable 1 & Stable 2 & Stable 3 & Stable 4 \\
\hline $1^{\text {st }}$ & Massage $n=14$ & Massage $n=10$ & Music $n=11$ & Music $n=10$ \\
& Control $n=6$ & Control $n=6$ & Massage $n=14$ & Massage $n=14$ \\
$2^{\text {nd }}$ & Music $n=14$ & Music $n=13$ & Control $n=6$ & Control $n=6$
\end{tabular}


Speaker ${ }^{\circledR}$, Pet Acoustic Inc, Washington, USA) also designed to be within the range of horse-hearing. The tool limits sound frequencies into $200 \mathrm{~Hz} \sim 12 \mathrm{KHz}$ and features a soft bass designed for listening comfort. The CD was played every day in the "Repeat All" mode. The volume was set in the mid-range; at about 65-70 decibels.

\section{Massaging routine}

In addition to the training routine, the horses from massage group were subjected to special long-lasting, relaxing physiotherapy. The horses received an overall-massage for 25-30 min, three days a week. The horses were always massaged after the training session and after collecting the saliva samples. For one week prior to the actual study, the horses were massaged to get them used to the technique. The primary massage session included: (1) laying hands on the horse, which is not, in fact, a proper massage technique but was used more to accustom the horse to contact; (2) friction, i.e. massage with a circular stroking motion applied across the horse's muscle, instead of restricting it to the direction of the muscle, tendons and ligaments; (3) petrissage, i.e. kneading some areas of the body to increase the circulation in the tissues. Petrissage helps soften and prepare the horse's muscle tissue for deeper equine therapy movements; (4) shaking used for increasing the local circulation and for improving the stretching of the horse's limbs; (5) and tapotement applied for stimulating the horses at the end of the massage session. The massage focused on four body areas: (1) the neck area ( $M$. trapezius, $M$. rhomboideus, $M$. splenius, $M$. serratus ventralis thoracis and M. brachiocephalicus); (2) the scapula, forearm and back (M. supraspinatus, $M$. infraspinatus, $M$. triceps brachii and $M$. latissimus dorsi); (3) the buttock ( $M$. gluteus superficjalis, M. gluteus medius, M. biceps femoris, M. semitendinosus and $M$. semimembranosus); (4) the hind limb ( $M$. extensor digitorum longus and $M$. flexor digitorum superficjalis). The massage was performed by four masseurs. They were well-trained specialists in the area of horse physiotherapy. The masseurs did not massage only one horse each but rotated amongst the horses.

\section{Saliva Cortisol Measurement}

The saliva samplings were conducted six times a year. The first sampling took place in March, i.e. at the beginning of race training, and just before introducing the music and massage in the experimental groups. Samples were taken every 28-35 days. Two saliva samples were collected from each horse: (1) in the early morning at rest - before the training session; (2) and immediately after the return of the horse from the track. The samples were collected with a small piece of sponge which was inserted into the horse's mouth and then, after soaking in the saliva, the sponge was placed in a plastic tube and stored at $-20^{\circ} \mathrm{C}$ until assayed, as described by Strzelec et al. (2011).

Before the laboratory analysis, the saliva samples were centrifuged at $500 \times \mathrm{g}$ for $15 \mathrm{~min}$ at room temperature. Next, the sponge with the straw was removed and the saliva was transferred to test tubes. The concentrations of cortisol in the saliva samples were measured by the enzyme-immunoassay method using the CORTISOL EIA kit (Diagnostic System Laboratories Inc., Webster, TX, USA). All the samples were analysed in duplicate. The absorbance was measured by a Multiscan reader (Labsystem, Helsinki, Finland) using the GENESIS $V$ 3.00 software program. The intra- and interassay CV for salivary cortisol determined in the laboratory amounted to $9 \%$ and $11 \%$. The results were expressed in $\mathrm{nmol} / \mathrm{L}$.

In spite of complying with the strict procedures, in some cases, the analysis of the cortisol level did not give any results because the absorbance was about the maximal value of the range of this method.

\section{Statistical Analysis}

The data were statistically analysed with the use of multivariate analysis of variance (ANOVA GLM; SAS software package, 2003) which considered the effect of the group (the control, music and massage groups), sex (stallions, mares), and the year of the study (first year, second year) as well as the interactions between those factors. The year of the study and the sex factors turned out to be insignificant and were not the subject of the study, hence only the group factor was discussed. The results are presented as the means with the standard deviations (SD). Tukey's multiple comparison test was used to identify the differences between the groups. Statistical significance was accepted at the level of $\mathrm{P}<0.05$.

\section{Results}

In the first measurement taken at rest, the groups did not differ with regard to the cortisol level. The salivary cortisol concentration determined at rest was significantly lower in music and massage groups, as compared to control group, in the second, third, fourth and sixth measurements (Figure 1). In the fifth measurement, the cortisol level in massage group was significantly lower than in music group. In the samples collected after training sessions finished for the day, the results of control and music groups did not differ significantly (Figure 2). However, in massage group's, the second and sixth measurement results were significantly lower than the results of control group. Moreover, the fifth and sixth measu-

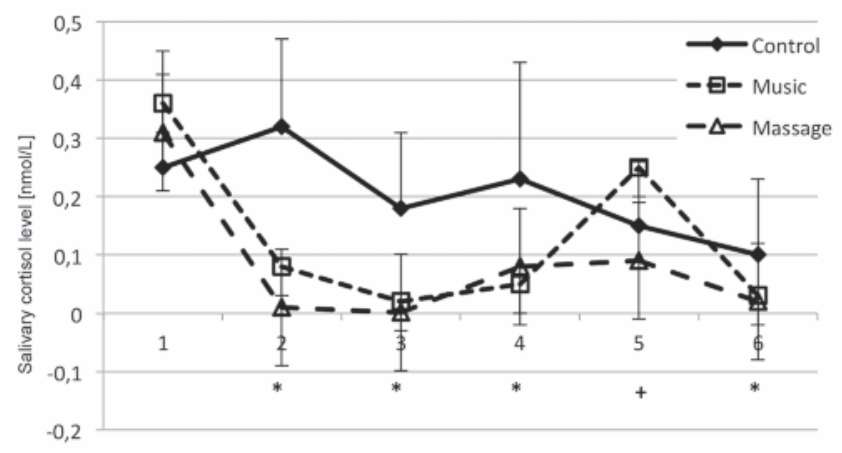

Fig. 1 Salivary cortisol level determined at rest in studied groups of horses during following months of the training season (means \pm SD). 1, 2, $3 \ldots$ = following months of the study; ${ }^{*}=$ means in Control Group differ significantly in comparison to other groups; $+=$ mean in massage group is significantly different than in music group. 
rement results of massage group were significantly lower than the results for music group. To simplify the graphs, in both Figures, the values of SD are presented as only upper or lower bars, nevertheless, each value of SD above the mean was equal with those below the mean.

The race performance parameters are presented in Table 2 . Horses in massage group achieved better results than those in control group with regard to the number of races won, prize per race and success coefficient. Music group had significantly higher prize per race than control group. All the studied performance parameters did not significantly differ between music and massage groups.

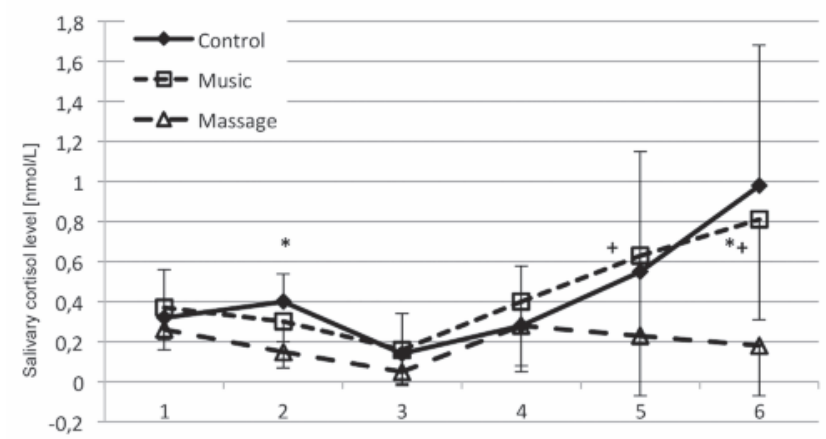

Fig. 2 Salivary cortisol level determined after the end of training sessions in studied groups of horses during following months of the training season (means \pm SD). 1, 2, $3 \ldots$ =following months of the study; ${ }^{*}=$ means in Massage Group are significantly different than in Control Group; +=means in Massage Group differ significantly, in comparison to Music Group.

\section{Discussion}

The results of the present study clearly show that both stresscoping methods (music meant to be relaxing in the stable and relaxing massage), brought positive effects. Introducing those methods significantly decreased the release of cortisol. The amount of cortisol was estimated on the basis of the salivary cortisol concentration. The use of this kind of stress-level estimation is commonly accepted in current research (Schmidt et al. 2010 a and b, Peeters et al. 2010).

The most interesting results concerned the determination of the cortisol level in saliva samples, taken at rest. The lack of differences in the first measurement taken at rest, showed that, as was expected, the three groups showed similar cortisol levels at the beginning of the study. The similarity of the groups was in accordance with the trainer's opinion on the normal behaviour of all of the horses. Both of the relaxation methods significantly decreased the cortisol release as com- pared to control group, during the whole racing season, excluding the fifth month of the study. It is worth noticing that the massage was performed after the training sessions, so the horses were massaged at noon, and they listened to music in the afternoon. The horses were investigated at rest, in the early morning, hence the influence of the relaxation methods was analysed many hours after the relaxation treatments. Our results indicate the long lasting effect of the relaxation methods on the salivary cortisol level in the race horses. The positive effect the massage had on the salivary cortisol level determined just after a treatment, was described earlier (Scott and Swenson 2009). In other study, massage reduced the stress level which had been evaluated on the basis of heart rate and behaviour of the horses also during a treatment (McBride et al. 2004). In the fifth month of the study, the horses which listened to music had a significantly higher salivary cortisol concentration than those horses which received a massage. An analysis of heart rate variability in horses which listened to relaxation music, also showed that the effectiveness of this method decreased after some months of the treatment (Stachurska et al. 2015). Perhaps animals get accustomed to the music as time passes. Moreover, the horses in general get accustomed to the training. A tendency to decrease in resting cortisol values was seen in control group during the study. Thus, probably, the salivary cortisol concentration dropped in music group in sixth measurement in comparison to the fifth measurement, because of a general tendency to adapt to the environment. However, the adaptation effects of long-lasting music treatment in humans and animals have been studied less. In fact, many reports describe beneficial effects of short-time use of relaxing music (Kıyıc et al. 2013, Bowman et al. 2015, Linnemann et al. 2015, 2016).

The analysis of those salivary cortisol samples taken after the daily training sessions, and taken in the fifth and sixth month of the study, showed the clear positive effect of the massage treatment over the music treatment. Exercise performed by race horses during training increases the salivary cortisol concentration (Kędzierski et al. 2013, 2014a), however, endurance exercise has a stronger effect (Desmecht et al. 1996). Some studies suggest that salivary cortisol level determined after exercise, can indicate the relative intensity of exercise in race horses (Kędzierski et al. 2013). Generally, the intensity of exercise increases with the duration of training. Therefore, the values of salivary cortisol obtained after the end of training sessions tended to increase, especially in control and music groups. In the following months of the study, we compared horses which were subjected to similar amounts of intensive exercise. Thus, the differences in the salivary cortisol concentration found between massage group and other groups were the evident effect of the massage treatment. Listening to music only appears to influence mental relaxation in the horses, whereas massage has an effect on both the mental and muscle

Table 2 Race performance parameters of the studied horses (means \pm SD)

\begin{tabular}{lcccc} 
Table 2 & Race performance parameters of the studied horses (means \pm SD) & & \\
\hline Group of horses & $\begin{array}{c}\text { Number of races } \\
\text { in which the horse won }\end{array}$ & $\begin{array}{c}\text { Sum of prices to number } \\
\text { of starts ratio }\end{array}$ & Success coefficient & General handicap \\
\hline Control & $0.54 \pm 0.38 \mathrm{a}$ & $301 \pm 142 \mathrm{a}$ & $0.90 \pm 0.09 \mathrm{a}$ & $55.9 \pm 10.5 \mathrm{a}$ \\
Music & $0.77 \pm 0.29 \mathrm{ab}$ & $554 \pm 141 \mathrm{~b}$ & $1.36 \pm 1.28 \mathrm{ab}$ & $61.1 \pm 12.2 \mathrm{a}$ \\
Massage & $0.89 \pm 0.14 \mathrm{~b}$ & $723 \pm 95.9 \mathrm{~b}$ & $1.26 \pm 0.31 \mathrm{~b}$ & $63.8 \pm 11.5 \mathrm{a}$ \\
\hline
\end{tabular}

Sum of prices is given in Euro. Success coefficient - the sum of prizes won by a horse, divided by the mean sum of prizes won by all horses at the same age in current race season. Means in columns marked with the same letters do not differ significantly at $p<0.05$ 
relaxation (Haussler 2009). It is not surprising that the estimated cortisol release after physical activity showed that massage brought more beneficial effects than the music. From the economic and management point of view, though, providing music is much easier than providing a relaxing massage.

The horses were exposed to such stressful stimuli as: the training routine, a restriction of movement during most of the day, and taking part in strong competition during races. Those stimuli had an influence on all of the horse groups. Other factors, like the conditions in the stables, the behaviour of the caretakers and trainers, may also affect the stress level in the horses. Horses are very sensitive to human behaviour (Baragli et al. 2009, Keeling et al. 2009, Birke et al. 2011). For this reason, the study was arranged in a manner which minimalized the influence of the stable and human factors and enabled the researches to focus on the influence of the massage, and music.

The benefits of the relaxing methods were also found in the race records. The prize per race was significantly higher in the experimental groups than in control group. Moreover, the number of races won and the success coefficient were higher in massage group. Hence, the performance of the horses treated with the relaxing methods was better which, in turn, had the economic importance. This fact shows that applying the relaxing methods is desired because of the race horse's welfare and performance.

\section{Conclusion}

In conclusion, both the relaxation massage and the music treatment significantly decreased the cortisol release in Purebred Arabian horses trained for racing. The massage treatment gave better results than listening to music which meant to be relaxing. Playing music, though, being easier to provide, may be widely introduced to improve the welfare and performance of race horses.

\section{Funding statement}

The Polish National Centre for Research and Development (grant number 180061) sponsored this study.

\section{Animal Welfare Statement}

The animal care and experimental procedures were in accordance with the European Committee regulations for the protection of experimental animals. The care and procedures were approved by Local Ethics Review Committee for Animal Experiments, the University of Life Sciences in Lublin, Poland (reference number 78/2012).

\section{References}

Alexander S. L., Irvine C. H. G. (1998) Stress in the racing horse: Coping vs not coping. J. Equine Sci. 9, 77-81

Baragli P., Gazzano A., Martelli F., Sighieri C. (2009) How do horses appraise humans' actions? A brief note over a practical way to assess stimulus perception. J. Equine Vet. Sci. 29, 739-742
Birke L., Hockenhull J., Creighton E., Pinno L., Mee J., Mills D. (2011) Horses' responses to variation in human approach. Appl. Anim. Behav. Sci. 134, 56-63

Bohák Z., Szabó F., Beckers J. F., Melo de Sousa N., Kutasi O., Nagy K., Szenci O. (2013) Monitoring the circadian rhythm of serum and salivary cortisol concentrations in the horse. Domest. Anim. Endocrinol. 45, 38-42

Bowman A., Scottish Spca, Dowell F. J., Evans N. P. (2015) 'Four Seasons' in an animal rescue centre; classical music reduces environmental stress in kennelled dogs. Physiol. Behav. 143, 70-82

Bregman M. R., Iversen J. R., Lichman D., Reinhart M., Patel A. D. (2012) A method for testing synchronization to a musical beat in domestic horses (Equus ferus caballus). Empir. Musicol. Rev. 7, 144-156

Carter C., Greening L. (2012) Auditory stimulation of the stabled equine; the effect of different music genres on behaviour. Proceedings of the 8th International Equitation Science Conference, Royal (Dick) Veterinary School, Edinburgh, 18th-20th July 2012 pp 167

Cayado P., Mu oz-Escassi B., Dominguez C., Manley W., Olabarri B., Sánchez de la Muela M., Castejon F., Mara on G., Vara E. (1996) Hormone response to training and competition in athletic horses. Equine Vet. J. Suppl. 36, 274-278

Desmecht D., Linden A., Amory H., Art T., Lekeux P. (1996) Relationship of plasma lactate production to cortisol release following completion of different types of sporting events in horses. Vet. Res. Commun. 20, 371-379

Evans D. L. (2003) Welfare of the racehorse during exercise training and racing. In: Waran N (ed) The Welfare of Horses, Springer, Netherlands pp 181-201

Fazio B., Medica P., Cravana C., Ferlazzo A. (2008) Effects of competition experience and transportation on the adrenocortical and thyroid responses of horses. Vet. Rec. 163, 713-716

Harewood E. J. (2005) Behavioral and physiological responses to stabling in naïve horses. J. Equine Vet. Sci. 25, 164-170

Haussler K. K. (2009) Review of manual therapy techniques in equine practice. J. Equine Vet. Sci. 29, 849-869

Henderson A. J. (2007) Don't Fence Me In: Managing Psychological Well Being for Elite Performance Horses. J. Appl. Anim. Welf. Sci. 10, 309-329

Keeling L. J., Jonare L., Lanneborn L. (2009) Investigating horsehuman interactions: the effect of a nervous human. Vet. J. 181, 70-71

Kędzierski W., Cywi ska A., Strzelec K., Kowalik S. (2014a) Changes in salivary and plasma cortisol levels in Purebred Arabian horses during race training session. Anim. Sci. J. 85, 313-317

Kędzierski W., Strzelec K., Cywi ska A., Kowalik S. (2013) Salivary cortisol concentration in exercised Thoroughbred horses. J. Equine Vet. Sci. 33, $1106-1109$

Kędzierski W., Wilk I., Janczarek I. (2014b) Physiological response to the first saddling and first mounting in horses: comparison of two sympathetic training methods. Anim. Sci. Pap. Rep. 32, 219-228

Kıyıcı J. M., Koçy g t R., Tüzemen N. (2013) The effect of classical music on milk production, milk components and milking characteristics of Holstein Friesian. J. Tekirdag Agric. Fac. 10, 74-81

Linnemann A., Ditzen B., Strahler J., Doerr J. M., Nater U. M. (2015) Music listening as a means of stress reduction in daily life. Psychoneuroendocrinology 60, 82-90

Linnemann A., Strahler J., Nater U. M. (2016) The stress-reducing effect of music listening varies depending on the social context. Psychoneuroendocrinology 72, 97-105

MacTaggart G., McGreevy P., Waran N., Phillips C. (2010) Development of a thoroughbred racehorse welfare educational index and associated programme for youth groups. In: 3rd Australasian Equine Science Symposium, 3-5 June pp 66

McBride S. D., Hemmings A., Robinson K. (2004) A preliminary study on the effect of massage to reduce stress in the horse. J. Equine Vet. Sci. 24, 76-81

Nagata S., Takeda F., Kurosawa M., Mima K., Hiraga A., Kai M., Taya K. (1999) Plasma adrenocorticotropin, cortisol and catecholamines response to various exercises. Equine Vet. J. Suppl. 30, 570-574 
Peeters M., Sulon J., Beckers J. F., Ledoux D., Vandeheede M. (201 1) Comparison between blood serum and salivary cortisol concentrations in horses using an adrenocorticotropic hormone challenge. Equine Vet. J. 43, 487-493

Peeters M., Sulon J., Serteyn D., Vandeheede M. (2010) Assessment of stress level in horses during competition using salivary cortisol: preliminary studies. J. Vet. Behav. 5, 216

Saslow C. A. (2002) Understanding the perceptual world of horses. Appl. Anim. Behav. Sci. 78, 209-224

Schmidt A., Aurich J., Möstl E., Müller J., Aurich C. (2010a) Changes in cortisol release and heart rate variability during the initial training of 3-year-old sport horses. Horm. Behav. 58, 628-636

Schmidt A., Möstl E., Wehnert C., Aurich J., Müller J., Aurich C. (2010b) Cortisol release and heart rate variability in horses during road transport. Horm. Behav. 57, 209-215

Scott M., Swenson L. A. (2009) Evaluating the benefits of Equine massage therapy: A review of the evidence and current practices. J. Equine Vet. Sci. 29, 687-697

Stachurska A., Janczarek I., Wilk I., Kędzierski W. (2015) Does music influence emotional state in race horses? J. Equine Vet. Sci. 35, 650-656

Strzelec K., Kankofer M., Pietrzak S. (2011) Cortisol concentration in the saliva of horses subjected to different kinds of exercise. Acta Vet. Brno 80, 101-105

van der Kolk J. H., Nachreiner R. F., Schott H. C., Refsal K. R., Zanella A. J. (2001) Salivary and plasma concentration of cortisol in normal horses and horses with Cushing's disease. Equine Vet. J. 33, $211-213$

Waters A. J., Nicol C. J., French N. P. (2002) Factors influencing the development of stereotypic and redirected behaviours in young horses: findings of a four year prospective epidemiological study. Equine Vet. J. 34, 572-579

Wells D. L. (2009) Sensory stimulation as environmental enrichment for captive animals: A review. Appl. Anim. Behav. Sci. 118, 1-11

Erweiterte Zusammenfassung

\section{Massage oder Musik führt beim Rennpferd zu einer Ver- minderung der Speichel-Cortisolkonzentration}

Junge Pferde werden zum Trainingsbeginn oft transportiert und in einer neven Umgebung aufgestallt. Dieser Transport, die Umstallung, Beginn des Trainings sowie Teilnahme an Rennen bedingt für Pferde chronischen Stress. Es ist bekannt, dass langanhaltender Stress einen negativen Einfluss auf die Gesundheit hat. Zur Reduzierung des Stresses gibt es unterschiedliche Ansätze wie Auslauf in einem Paddock, Musik oder Massage. Beim Pferd konnte nachgewiesen werden, dass unter Massage die Herzfrequenz sinkt. Musik beruhigt Pferde ebenfalls wobei die Art der gewählten Musik durchaus Einfluss hat. Allerdings ist wenig darüber bekannt, inwiefern diese Methoden einen chronischen Stress bei Rennpferden beeinflussen. Zur Erfassung von mentalem Stress stellt die Erhebung des Kortisolspiegels im Speichel zurzeit eine einfach durchzuführende und anerkannte Methode dar. Ziel dieser Studie war es, den Einfluss einer entspannenden Massage und von im Stall gespielter Musik auf den Stresspegel von Pferden mit Hilfe der Kortisolkonzentration im Speichel zu beurteilen. Die Studienpopulation umfasste 120 klinisch gesunde Araber, die im Rahmen ihrer ersten Rennsaison über zwei Jahre untersucht wurden, 57 Pferde im ersten und 63 Tiere im zweiten Jahr. Die Studiendaver betrug jeweils 6
Monate. Zu Beginn waren die Araber 28-31 Monate alt. Die Tiere wurden vom Gestüt zum Rennstall gebracht und dort über einen Monat akklimatisiert, anschließend begann das Training. Über die folgenden 9-12 Tage sollten die Pferde an den Reiter gewöhnt werden, über die folgenden 6 Wochen wurden die Tiere über 30 Minuten geritten, gefolgt kontinuierlich gesteigertem Training. Die Pferde waren per Zufallsprinzip in drei Gruppen aufgeteilt worden: Musikgruppe, Massage- und Kontrollgruppe. Alle Pferde waren auf Stroh aufgestallt, erhielten die gleiche Futterration und dasselbe Personal versorgte die Tiere. Die Pferde wurden 6 Tage in der Woche über $1 \mathrm{~h}$ trainiert, nach drei Trainingsmonaten starteten sie das erste Rennen. Am Ende beider Rennsaisons wurde die Leistung der Pferde beurteilt über Anzahl der gewonnenen Rennen, Preisgeld pro Rennen, Erfolgskoeffizient sowie generelles Handicap. In der Musikgruppe wurde an fünf Tagen die Woche von 13 bis 18 Uhr eine speziell komponierte Musik abgespielt. Die Pferde der Massagegruppe wurden an drei Tagen in der Woche physiotherapeutisch über 25-30 Minuten behandelt und zwar nach dem Training und nach Entnahme der Speichelproben. Die Massage umfasste 1. einfaches Auflegen der Hände, 2. Massage der Muskulatur mit kreisförmigen Bewegungen, 3. knetende Massage, 4. Schüttel sowie Klopfmassage. Die spezifischen massierten Regionen waren Genickregion, Scapula, Vorderbein, Rücken, HintergliedmaBe und Kruppe einschließlich M. semimembranosus, M. semitendinosus. Die Speichelproben wurden über 6 Monate monatlich genommen. Die erste Probennahme erfolgte zu Beginn des Renntrainings, vor der Einführung der Musik und Massage. Die Kortisolkonzentration wurde mittels EnzymImmunoassay analysiert.

Die ersten Messungen vor Beginn des Renntrainings unterschieden sich bezüglich der Gruppenzugehörigkeit nicht. Bei der zweiten, dritten, vierten und sechsten Messung waren die Konzentrationen bei Pferden der Musik- oder Massagegruppe signifikant niedriger im Vergleich zu den Kontrolltieren. Bei der fünften Messung waren die Werte bei Pferden der Massagegruppe signifikant niedriger als bei Tieren der Musikgruppe. Auch konnte festgestellt werden, dass Pferde der Massagegruppe bessere Rennergebnisse erzielten als Pferde der Kontrollgruppe und zwar in Hinblick auf Anzahl gewonnener Rennen, Preisgeld pro Rennen und Erfolgskoeffizient. Somit konnten beide Verfahren - mit Ausnahme des fünften Monats in der Musikgruppe - eine Stressreduzierung während der Rennsaison erzielen. Letzteres Ergebnis könnte auf einem Gewöhnungseffekt beruhen. Die Ergebnisse des fünften und sechsten Monats deuten auf eine bessere Entspannung der Pferde durch Massage hin. Da die Probenentnahme morgens mehrere Stunden nach den Entspannungsmassage erfolgte, hält der erzielte Effekt über längere Zeit an. Bei Pferden der Kontrollgruppe und bei Tieren der Musikgruppe stiegen die Kortisolwerte in den letzten zwei Untersuchungsmonaten wieder an, eventuell könnte dies auf dem zunehmend höheren Trainingsniveau beruhen.

Schlüsselwörter: Tierschutz, Cortisol, Rennpferd, Massage, Musik, Stress, Pferd 